\title{
NUMERICAL SIMULATION OF DYNAMIC SHEAR TESTS FOR HIGH-STRENGTH STEELS SPECIMENS
}

\author{
Ievhen Kondriakov; Valeriy Kharchenko
}

\author{
G. S. Pisarenko Institute for Problems of Strength of the NAS of Ukraine, \\ Kyiv, Ukraine
}

\begin{abstract}
Summary. A series of numerical calculations using the finite element method was carried out to develop a dynamic shear testing method for high-strength steels specimens. The shape of the specimens with two shear zones was chosen for investigations. Obtained results made it possible to choose the optimal specimen size and loading scheme for realizing pure shear conditions. Using the Johnson-Cook model, taking into account the effect of the strain rate, the fracture of the specimens of armored steel Armox 500T was simulated using the appropriate fracture criterion. Obtained results showed that such a specimen design and loading scheme should ensure the implementation of pure shear conditions.
\end{abstract}

Key words: dynamic shear, strain rate, finite element method, high-strength steels.

https://doi.org/10.33108/visnyk_tntu2021.02.110

Received 30.03.2021

Statement of the problem. Shear failure occurs in many structural elements, where there are large shear loads at both low and high strain rates. During dynamic loads such as forging, pressure forming, high-speed machining, accidents and ballistic loads can cause shear failure of the materials with subsequent loss of load-bearing capacity, so for high-strength and armored sheet steels, in addition to uniaxial tensile tests, it is important to perform additional shear tests. Shear failure analysis is of great importance to ensure the safe operation of structural elements and improve existing regulations.

Analysis of available research. In recent years, the properties of shear fracture of materials have been intensively studied using various methods. A large number of loading techniques and specimen types have been developed for dynamic shear tests. The most widely used methods today include the use of drop weight impact testing machine [1], horizontal shear systems [2], air guns [3], impact on an inclined plate and others. Using special specimen designs, the shear strain can be limited by the cross-sectional size due to geometric inhomogeneity, for example: cap-shaped specimens [4], specimens with a double shear zone [5], with a cylindrical or flat cap [6], stepped or dumbbell-shaped [7] with single or double edge [8], compression or tension shear [9]. In some other specimens, the shear occurs due to asymmetry or inhomogeneity of the stress-strain state in the material, for example: compression/shear [10], truncated cone [11], punching [12], indentation [13]. Features of different types of specimens for shear tests are described in detail in Dodd [14] and Meyer [15].

One of the main problems in dynamic tests is to achieve conditions of pure shear. Under impact load, the mechanical behavior of the material is influenced by the combined effect of two factors - the strain rate and stress state. To study the independent effect of the strain rate, it is important to separate these effects and achieve a stress state with advantage of shear. However, when using the specimens described above, a combined stress state of shearcompression or shear-tension is usually obtained. At characteristic values of the Poisson's ratio 
of the material, it is impossible to avoid the influence of the stress state, so in such tests it is difficult to investigate the influence of strain rate. Another problem is the comparability and compliance of the properties of the material under different load conditions. The accuracy of the experimental data depends on both the test equipment and the type of specimen. At high strain rates, especially due to inertial effects and the propagation of stress waves in the material, each change in the geometry of the specimen and the loading technique can make significant changes in the behavior of the specimen and the results obtained. Therefore, to avoid such problems, it is desirable to carry out test on one type of specimens in the widest possible range of strain rates [16]. However, to date, there are very few studies known which use a single specimen type in a wide range of strain rates. One type of specimen that allows for pure shear conditions and testing in a wide range of strain rates is the two-shear specimen, first proposed by Ferguson [17] and subsequently modified and used by many scientists [18-22].

At present, there are no regulations neither in Ukraine nor in the world on testing of steels in the impact shear conditions, so the development of such a technique is very important and requires comprehensive experimental calculations, especially for high-strength and armored steels.

Objective of the research is application of the numerical simulation results of dynamic displacement tests of high-strength steels specimens for further development of experimental methods for conducting such tests.

Statement of the task. Studying the influence of various factors, such as: specimen geometry, load scheme, material model, etc. for developing methods for conducting dynamic shear tests, taking into account the analysis of literature sources and the world practical experience and using numerical simulation.

Scheme of the problem. According to the results of the analysis of literature sources and modern methods of impact shear tests, the shape of the specimen with two shear zones was chosen for the research, as shown in Fig. 1. To optimize the load scheme and implement the conditions of pure shear, a series of numerical calculations were performed, in which various parameters varied, such as specimen size and shear zones, striker size, load velocity, boundary conditions, etc.

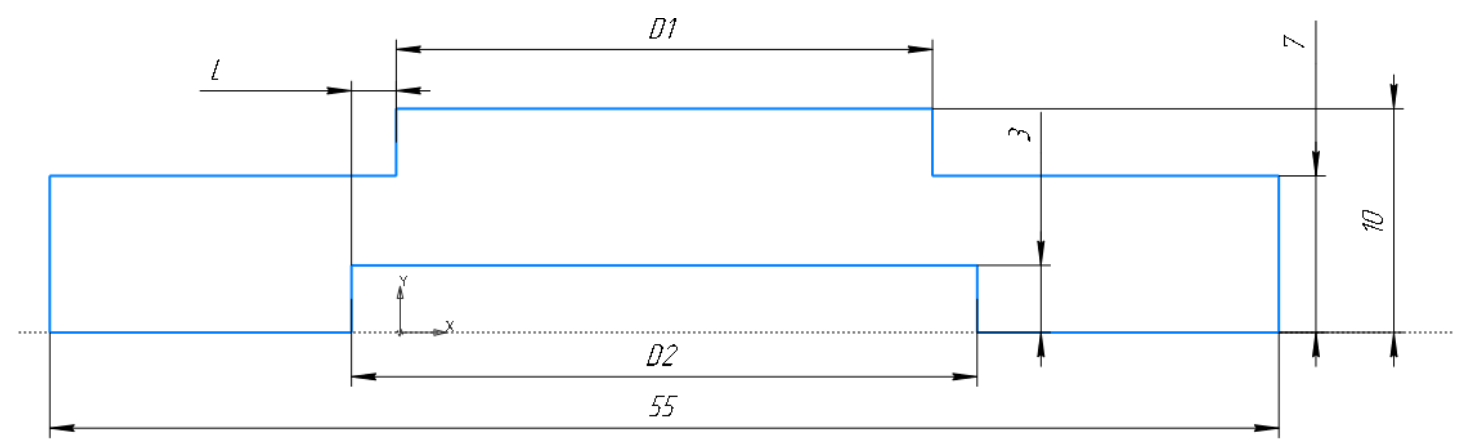

Figure 1. Geometric configuration of the impact shear specimen

The length $\mathrm{L}$ of the shear zones can be changed to create different strain rates in these zones. With this specimen design, the compression strain that occurs in its upper part is converted into a local shear in the respective zones. This specimen can be tested both for static shear using standard servo-hydraulic machines, and for dynamic shear using different types of drop-towers. Herewith, the strain rate can vary within the range of $10^{-3} \div 10^{5} \mathrm{c}^{-1}$. 
Using equation (1), the values of shear strain rate $\dot{\gamma}(t)$, stress $\tau(t)$ and shear strain $\gamma(t)$ can be calculated in the respective zones of the specimen:

$$
\left\{\begin{array}{l}
\dot{\gamma}(t)=\frac{V(t)}{L} \\
\tau(t)=\frac{F(t)}{2 A_{s z}}, \\
\gamma(t)=\frac{\Delta L(t)}{L}
\end{array},\right.
$$

where $\mathrm{A}_{\mathrm{sz}}$ is the cross-sectional area of the shear zone; $\mathrm{F}$ - force in the striker, $\mathrm{L}$ - length of the shear zone; $\Delta \mathrm{L}$ - relative displacement of the striker.

Numerical simulations were performed using the finite element method (FEM). The main aim of the calculations was to select such parameters of load and geometry of the specimen, which provide conditions as close to pure shear as possible. For this purpose, for all calculations there were built dependences of axial strains and stresses on time in different elements of the striker, dependence on time and distribution field of all components of strains and stresses in the middle part of the specimen shear zone, as well as changes in time of striker loading speed.

The parameters of the material model for steel 20, which was considered to be perfectly plastic $(\mathrm{E}=2.1 * 105 \mathrm{MPa}, \mu=0.3, \sigma \mathrm{T}=294.7 \mathrm{MPa})$, were used for test calculations. All calculations were performed for the $1 / 2$ part of the model with the corresponding symmetry conditions. It is known that the size of finite elements (FE) significantly affects the results of numerical simulations, so a series of calculations was performed using different densities of the FE grid. The results of the calculations showed that the optimal model is with a minimum FE size in the shear zone of $50 \mu \mathrm{m}$.

To study the influence of the geometry of the specimen on the process of its deformation and fracture, the following parameters were varied: length $L$ and shape of the shear zone, radii of chamfers R. One of the most important geometric parameters of the specimen which influences the strain rate is the length of the shear zone. The values $L=0,0.7,1,1.5,2$ and 4 $\mathrm{mm}$ were used in the calculations.

The load was carried out at a speed of $5 \mathrm{~m} / \mathrm{s}$ and an impact energy of $300 \mathrm{~J}$, which corresponds to the load parameters in standard drop weight and pendulum impact testers. The first calculations showed that the impact energy is insufficient to create conditions close to pure shear, so it was proposed to change the geometry of the specimen by adding $0.5 \mathrm{~mm}$, grooves at the top and bottom as shown in Fig. 2. Thus, the area of the shear zone was reduced, which allowed to achieve better results.

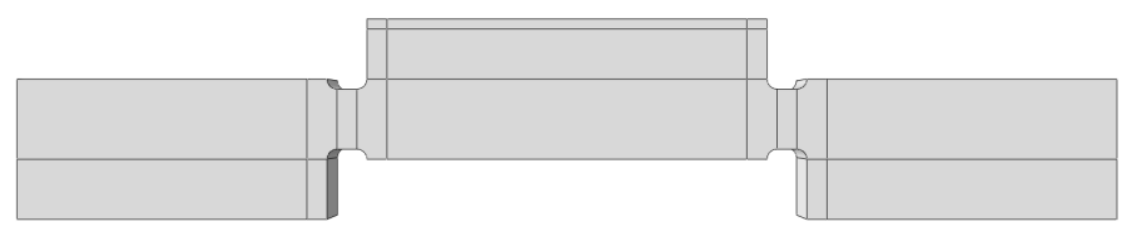

a)

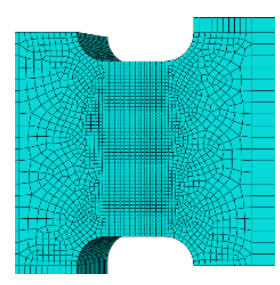

b)

Figure 2. Geometry model (a) and finite-element mesh (b) of the grooved specimen 
Analysis of results. The following are the results of calculations for 3 variants of specimens with a shear zone length $\mathrm{L}=0.7,2$ and $4 \mathrm{~mm}$ for steel 20 under the same load conditions. In Fig. 3 the distribution fields of shear strains $\varepsilon_{x y}$ for specimens with length $\mathrm{L}=0.7$ mm (Fig. 3, a), $2 \mathrm{~mm}$ (Fig. 3, b) and $4 \mathrm{~mm}$ (Fig. 3, c) are shown. It is seen that with increasing length $\mathrm{L}$ the area of pure shear decreases and is localized in the middle part. The maximum level of strain is reached in the area of concentrators.

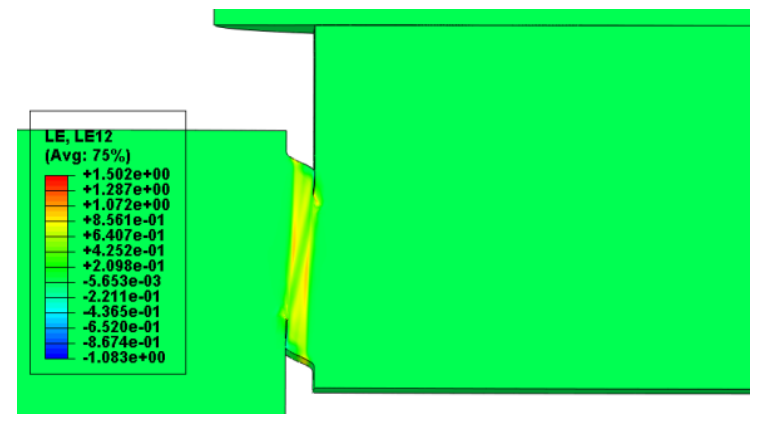

a)

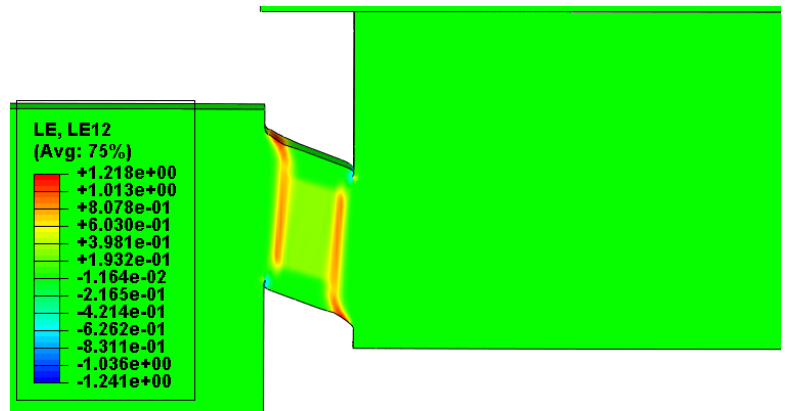

b)

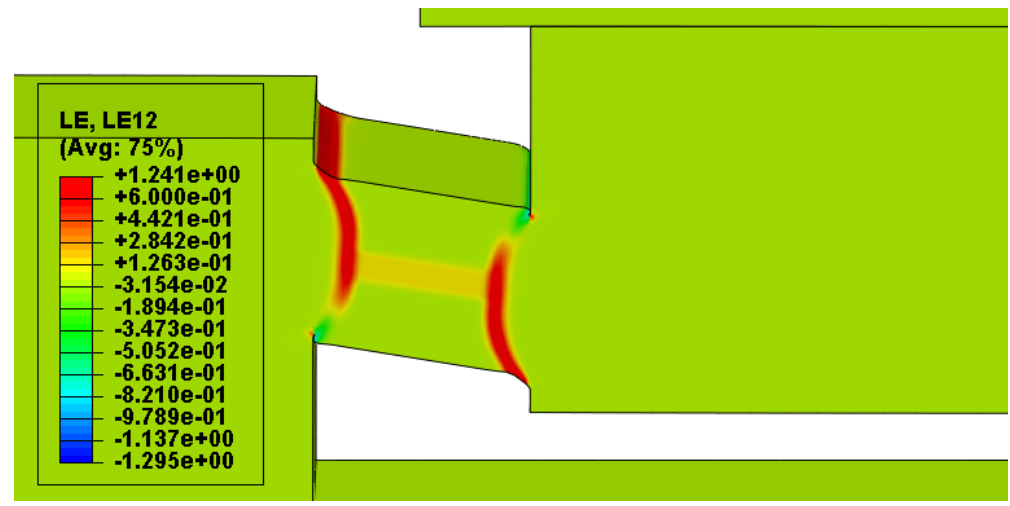

c)

Figure 3. Distribution of shear strains $\varepsilon_{\mathrm{xy}}$ for specimens with length $\mathrm{L}=0.7 \mathrm{~mm}(\mathrm{a}), 2 \mathrm{~mm}$ (b), and $4 \mathrm{~mm}$ (c)

In Fig. 4, the distribution of stress and strain components in the middle part of the shear zone for specimens with $\mathrm{L}=4 \mathrm{~mm}$ are shown. It is seen that during the whole loading process the components $\sigma_{12}$ and $\varepsilon_{12}$ predominate in the shear zone. The stresses $\sigma_{12}$ increase very quickly and hardly change during the loading process. The $\varepsilon_{12}$ strains increase slowly throughout the load process and their values are much higher than the values of the other components.

Thus, the stress state of the material in the local shear zone can be considered as pure shear. In this case, with increasing $\mathrm{L}$, the stress $\sigma_{12}$ almost does not change, while the other stress components with increasing $\mathrm{L}$ decrease. The magnitude of the shear strains $\varepsilon_{12}$ decreases with increasing length of the shear zone L. Therefore, the smaller the length $\mathrm{L}$ is, the greater the strain rate, which is the confirmation of the dependences (1). 
To reduce the shear zone and, accordingly, the energy required to break the specimen, a model with additional side grooves for the specimen with a length of $\mathrm{L}=4 \mathrm{~mm}$ was built. In Fig. 5 a geometric model and FE mesh of the specimen with side grooves of $3 \mathrm{~mm}$ on each side are shown.

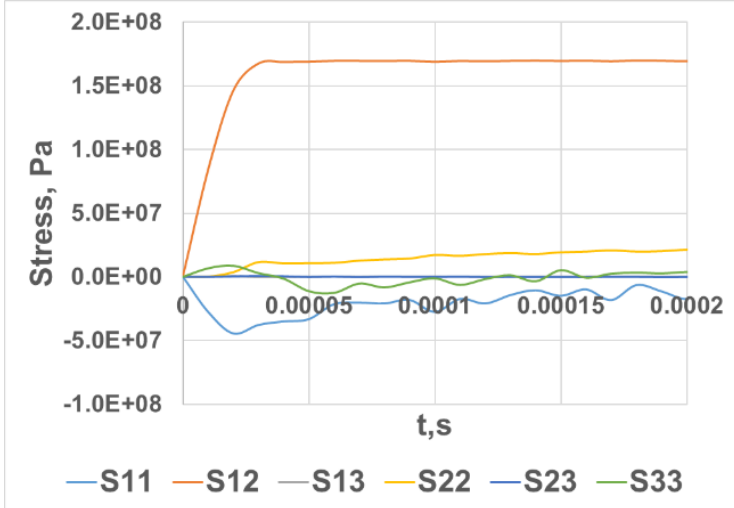

a)

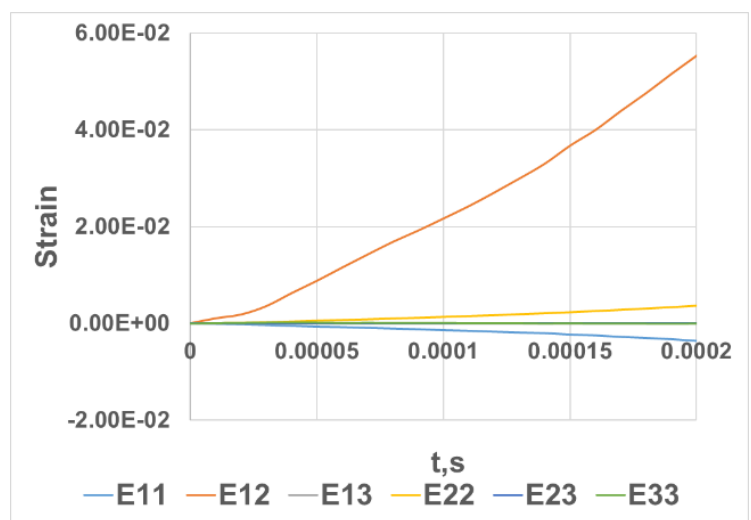

b)

Figure 4. Distribution of stress components (a) and strain components (b) in the middle part of the shear zone for specimens with $\mathrm{L}=4 \mathrm{~mm}$

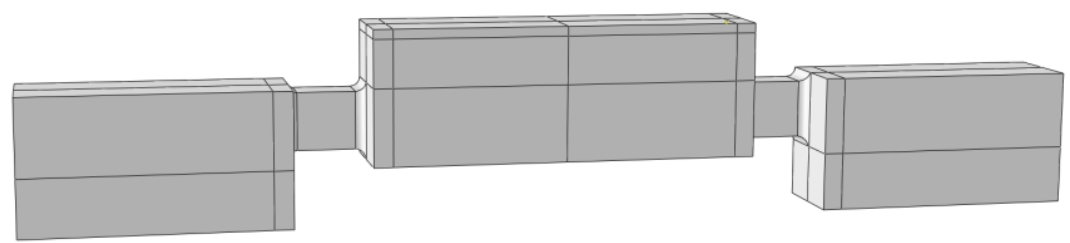

a)

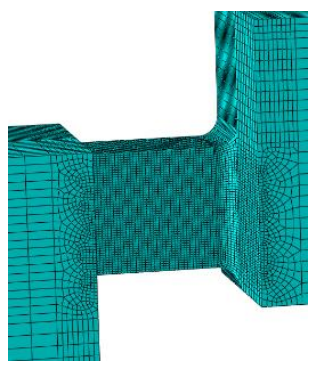

b)

Figure 5. Geometry model (a) and finite-element mesh (b) of the side-grooved specimen

As can be seen in Fig. 6, shear strains increase with the addition of side grooves, respectively, the strain conditions are closer to pure shear, but the manufacture of such side grooved specimens is technologically more complex and expensive.

In numerical simulation, the radii of the chamfers of the grooves in the shear zone can be taken as $r=0$, but in the manufacture of specimens, these radii will always be $>0$. To study the effect of the radii of the grooves, numerical simulations were performed for $r=0.1,0.25$ and $0.5 \mathrm{~mm}$. In Fig. 7, the change in time of axial stresses in the dynamometer during numerical simulation of specimens with $\mathrm{r}=0.25$ and $0.5 \mathrm{~mm}$, as well as $\mathrm{L}=1$ and 2 $\mathrm{mm}$ is shown. As can be seen, the difference in the obtained results is almost absent, but in the literature there is evidence of a significant effect of the value of the radii of the chamfers [21], especially when reducing the length of the shear zone L to 0 . Therefore, when developing an experimental technique, it is necessary to take into account the peculiarities of deformation and fracture of specimens with different radii of chamfers and the length of shear zones. 
Due to the special design of the specimen, a large stress gradient is observed in the loading and support parts of the specimen around the shear zone, while in the shear zone itself the stresses are quite homogeneous. Small concentration of stresses is observed in the chamfer area. The distribution of plastic strains in the central part of the shear zone is also homogeneous, while in the loading and support part of the specimen there are no plastic strains. Because of concentration of plastic strains in the chamfer area, the specimen fracture should start in these places and should occur in the shear area in the diagonal direction.

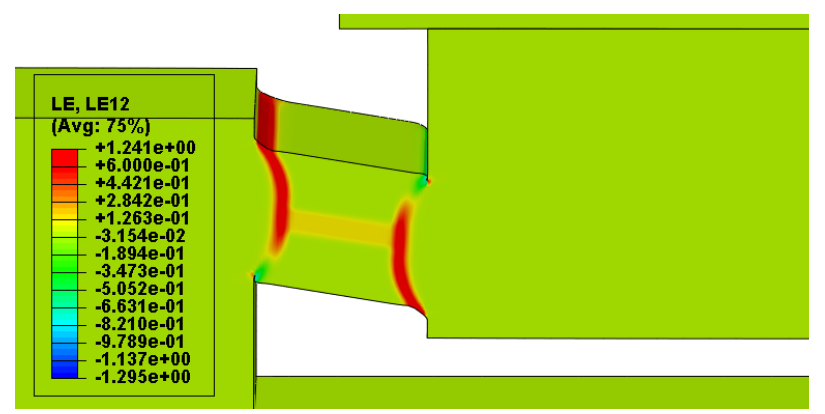

a)

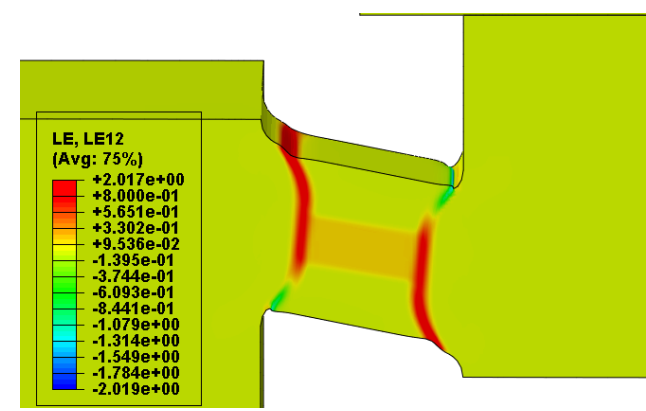

b)

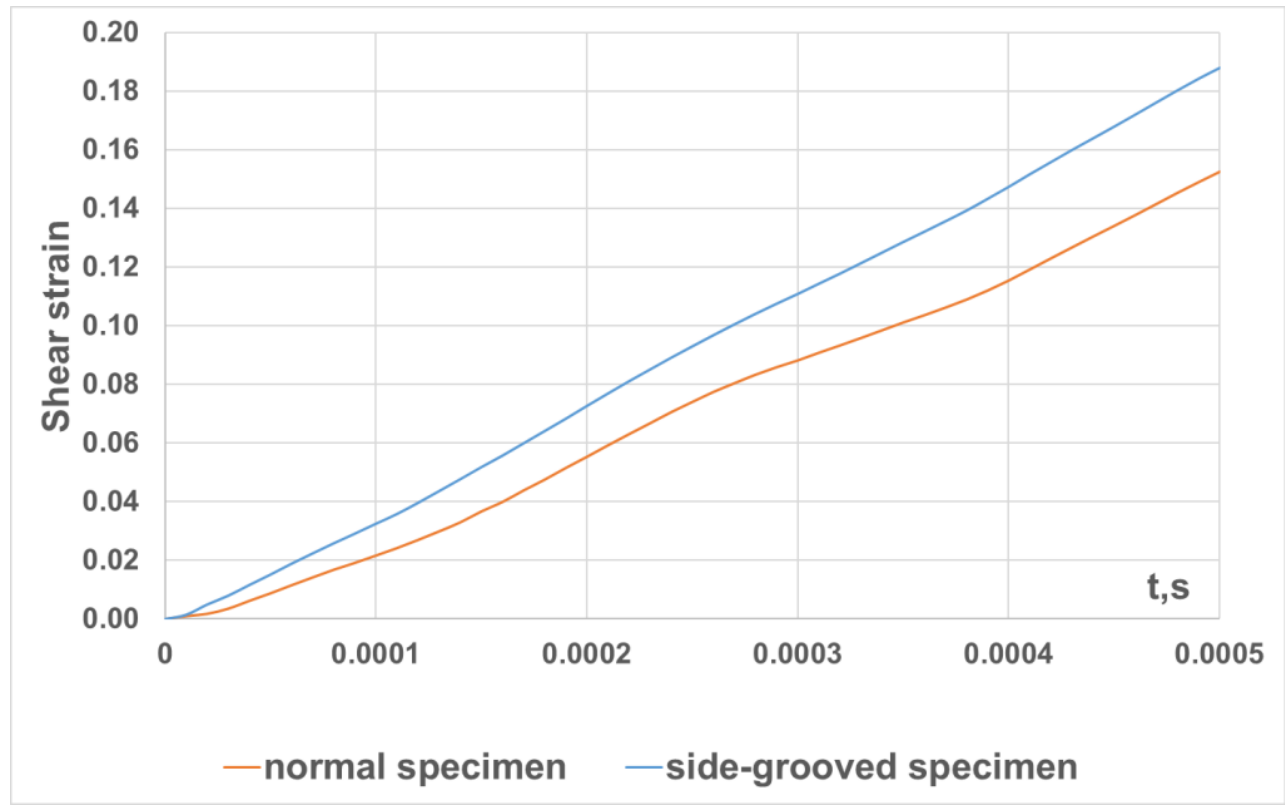

c)

Figure 6. Distribution of shear strains in normal specimens (a) and side-grooved specimens (b), and time variation of shear strains in the central part of the specimen shear zone (c)

To study the nature of the specimen fracture, calculations were performed using the Johnson-Cook model with the appropriate fracture criterion.

Strain hardening of the material is written by the equation:

$$
\sigma=\left(A+B \varepsilon^{n}\right)\left(1+C \ln \dot{\varepsilon}^{*}\right)\left(1-T^{* m}\right),
$$


where A, B, C, n, m are model parameters, which are determined by the results of complex tests.

Johnson and Cook [23] modernized the failure criterion proposed by Hancock and Mackenzie [24] by including the influence of strain trajectory, strain rate, and temperature in the expression of fracture strain, in addition to three-axis stress state:

$$
\bar{\varepsilon}_{f}^{p l}\left(\frac{\sigma_{m}}{\bar{\sigma}}, \dot{\bar{\varepsilon}}^{p l}, \hat{T}\right)=\left[D_{1}+D_{2} \exp \left(D_{3} \frac{\sigma_{m}}{\bar{\sigma}}\right)\right]\left[1+D_{4} \ln \left(\frac{\dot{\bar{\varepsilon}}^{p l}}{\dot{\varepsilon}_{0}}\right)\right]\left[1+D_{5} \hat{T}\right]
$$

where $\mathrm{D}_{1}-\mathrm{D}_{5}$ are the parameters of the material, determined by the results of various tests.

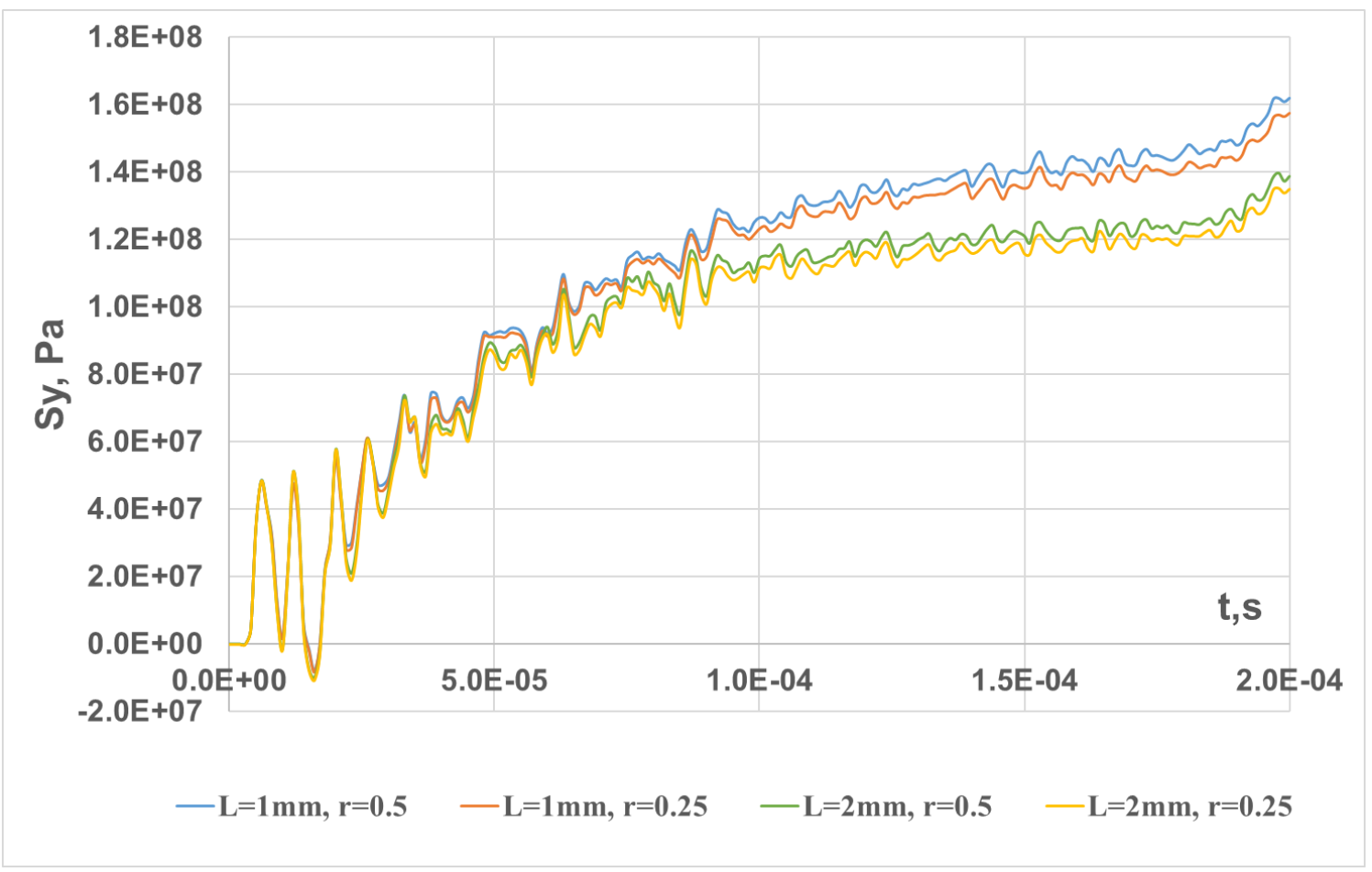

Figure 7. Time variation diagrams of axial stresses in the impactor for different corner radii $r$ and length of the shear zone $L$

To calculate the process of strain and fracture of the specimen, the following values of the parameters of the Johnson-Cook model for armored steel Armox 500T were set [25]: Young's modulus $\mathrm{E}=2.01 * 10^{11} \mathrm{~Pa}$, Poisson's ratio $\mu=0.33$, density $\rho=7850 \mathrm{~kg} / \mathrm{m}^{3}$, model parameters of Johnson-Cook $-\mathrm{A}=1387 * 106 \mathrm{~Pa}, \mathrm{~B}=835^{*} 106 \mathrm{~Pa}, \mathrm{C}=0.0617, \mathrm{n}=0.25$, $\mathrm{m}=1, \dot{\varepsilon}_{0}=1$, the parameters of Johnson-Cook's fracture criterion $-\mathrm{D}_{1}=0.04289, \mathrm{D}_{2}=2.1521$, $\mathrm{D}_{3}=-2.7575, \mathrm{D}_{4}=-0.0066, \mathrm{D}_{5}=0$.

The calculations results showed that the failure initiation occurs at time $\mathrm{t}=528 \mu \mathrm{s}$ in the zones of stress concentrators (chamfers). Then the crack propagates along the shear zone (Fig. 8). Thus, such a specimen design and the load scheme have to ensure the implementation of pure shear conditions. 


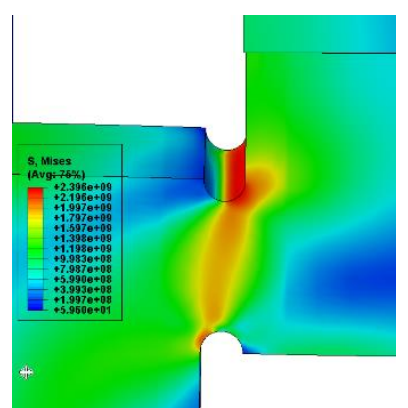

a)

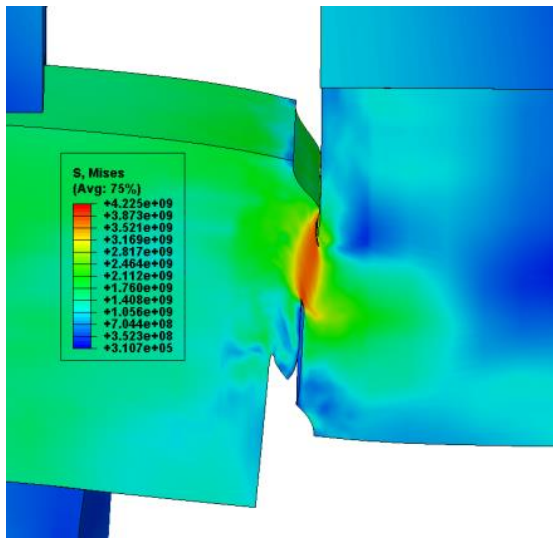

d)

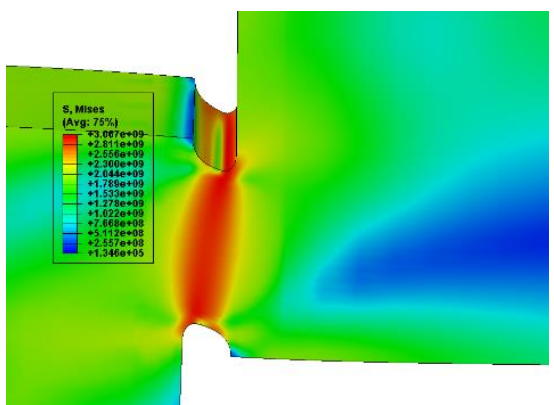

b)

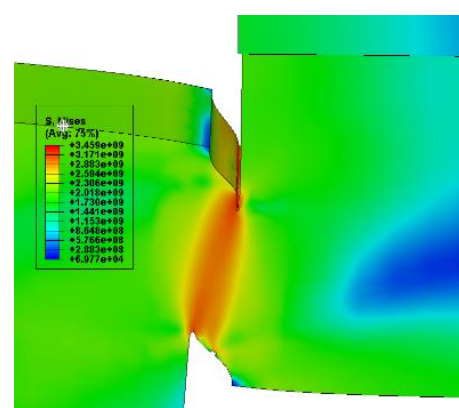

c)

Figure 8. Distribution of equivalent stresses at different points in time: (a) $-t=96 \mu \mathrm{s},(\mathrm{b})-\mathrm{t}=300 \mu \mathrm{s}$, (c) $-\mathrm{t}=528 \mu \mathrm{s},(\mathrm{d})-\mathrm{t}=688 \mu \mathrm{s},(\mathrm{e})-\mathrm{t}=704 \mu \mathrm{s}$

Conclusions. Using the finite element method, numerical simulation of dynamic shear of specimens was performed. The influence of specimen geometry, loading scheme and material model on the processes of deformation and fracture of specimens is investigated. Based on the results of numerical calculations, the optimal parameters of the load scheme and specimens design with two shear zones were selected to develop a technique for conducting dynamic shear tests.

\section{References}

1. Meyer L.W., Kruger L. Drop-weight compression shear testing. ASM handbook, mechanical testing and evaluation. 2000. Vol. 8. P. 452-454.

2. Wright T. W. The Physics and Mathematics of Shear Bands. Cambridge Monographs on Mechanics. Cambridge University Press. 2002. 260 p.

3. Klepaczko J. R. An experimental technique for shear testing at high and very high strain rates. The case of a mild steel. International Journal of Impact Engineering. 1994. Vol. 15. No. 1. P. 25-39. DOI: https://doi.org/10.1016/S0734-743X(05)80005-3

4. Pursche F., Meyer L. W. Correlation between dynamic material behavior and adiabatic shear phenomenon for quenched and tempered steels. Engineering Transactions. 2011. Vol. 59. No. 2. P. 67-84.

5. Xu Z., Ding X., Zhang W., Huang F. A novel method in dynamic shear testing of bulk materials using the traditional SHPB technique. Int. J. Impact Eng. 2017. Vol. 101. P. 90-104. DOI: https://doi.org/10.1016/j.ijimpeng.2016.11.012 
6. Clos R., Schreppel U., Veit P. Temperature, microstructure and mechanical response during shear-band formation in different metallic materials. Journal de Physique. 2003. Vol. 110. No. 4. P. 111-116. DOI: https://doi.org/10.1051/jp4:20020679

7. Wei Z., Li Y., Li J., Hu S. Formation mechanism of adiabatic shear band in Tungsten heavy alloys. Acta metallurgica sinica. 2000. Vol. 36. No. 12. P. 1263-1268. [In Chinese].

8. Kalthoff J. F. Modes of dynamic shear failure in solids. International Journal of Fracture. 2000. Vol. 101. P. 1-31. DOI: https://doi.org/10.1023/A:1007647800529

9. Dorogoy A., Rittel D., Godinger A. A shear-tension specimen for large strain testing. Experimental Mechanics. 2015. Vol. 56. No. 3. P. 437-449. DOI: https://doi.org/10.1007/s11340-015-0106-1

10. Meyer L. W., Staskewitsch E., Burblies A. Adiabatic shear failure under biaxial dynamic compression/shear loading. Mechanics of Materials. 1994. Vol. 17. No. 2-3. P. $203-214$. DOI: https://doi.org/10.1016/0167-6636(94)90060-4

11. Yu J., Li J, Wei Z. Researches on adiabatic shear failure of tungsten heavy alloy and Ti6Al4V alloy. J. Ningbo Univ. 2003. Vol. 16. No. 4. P. 417-428. DOI: https://doi.org/10.1046/j.1525-139X.2003.16092.x

12. Dowling A. R., Harding J., Campbell J. D. The dynamic punching of metals. Journal of Institute of Metals. 1970. Vol. 98. P. 215-224.

13. Meyer L. W., Andrade U. R., Chokshi A. H. The effect of grain size on the high-strain, high-strain-rate behavior of copper. Metallurgical and Materials Transactions A. 1995. Vol. 26. P. 2881-2893. DOI: https://doi.org/10.1007/BF02669646

14. Dodd B., Bai Y. Adiabatic shear localization: frontiers and advances. Elsevier, London. 2012. 468 p.

15. Meyer L. W., Halle T. Shear strength and shear failure, overview of testing and behavior of ductile metals. Mech. Time-Depend Mater. 2011. Vol. 15. P. 327-340. DOI: https://doi.org/10.1007/s11043-010-9113-x

16. Rittel D., Lee S., Ravichandran G. A Shear-compression specimen for large strain testing. Exp. Mech. 2002. Vol. 42. P. 58-64. DOI: https://doi.org/10.1007/BF02411052

17. Ferguson W. G., Hauser F. E., Dorn J. E. Dislocation damping in zinc single crystals. Brit. J. Appl. Phys. 1967. Vol. 18. P. 411-417. DOI: https://doi.org/10.1088/0508-3443/18/4/304

18. Stepanov G. V. Uprugoplasticheskoe deformirovanie i razrushenie materialov pri impul'snom nagruzhenii. Kiev: Nauk. dumka, 1991. 288 p. [In Russian].

19. Stepanov G. V., Fedorchuk V. A. Lokalizovanny`j sdvig v metallakh pri udarnom nagruzhenii. Problemy` prochnosti. 2000. No. 2. P. 27-42. [In Russian].

20.Xu Z., Ding X., Zhang W., Huang F. A novel method in dynamic shear testing of bulk materials using the traditional SHPB technique. Int. J. Impact Eng. 2017. Vol. 101. P. 90-104. DOI: https://doi.org/10.1016/j.ijimpeng.2016.11.012

21. Peirs J. et al. The use of hat-shaped specimens to study the high strain rate shear behaviour of Ti-6Al-4V. International Journal of Impact Engineering. 2010. Vol. 37. P. 703-714. DOI: https://doi.org/10.1016/j.ijimpeng.2009.08.002

22. $\mathrm{Xu} \mathrm{Z}$. et al. Plastic behavior and failure mechanism of Ti-6Al-4V under quasi-static and dynamic shear loading. International Journal of Impact Engineering. 2019. Vol. 130. P. 281-291. DOI: https://doi.org/10.1016/j.ijimpeng.2019.04.008

23. Johnson G. R, Cook W. H. Fracture characteristics of three metals subjected to various strains, strain rates, temperatures and pressures. Eng. Fracture Mech. 1985. Vol. 21. P. 31-48. DOI: https://doi.org/10.1016/0013-7944(85)90052-9

24. Hancock J. W., Mackenzie A. C. On the mechanisms of ductile failure in high-strength steels subjected to multi-axial stress-states. J. Mech. Phys. Solids. 1976. Vol. 24. P. 147-169. DOI: https://doi.org/10.1016/0022-5096(76)90024-7

25. Iqbal M. A., Senthil K., Sharma P., Gupta N. K. An investigation of the constitutive behavior of Armox $500 \mathrm{~T}$ steel and armor piercing incendiary projectile material. International Journal of Impact Engineering. 2016. Vol. 96. P. 146-164. DOI: https://doi.org/10.1016/j.ijimpeng.2016.05.017

\section{Список використаної літератури}

1. Meyer L.W., Kruger L. Drop-weight compression shear testing. ASM handbook, mechanical testing and evaluation. 2000. Vol. 8. P. 452-454.

2. Wright T. W. The Physics and Mathematics of Shear Bands. Cambridge Monographs on Mechanics. Cambridge University Press. 2002. 260 p.

3. Klepaczko J. R. An experimental technique for shear testing at high and very high strain rates. The case of a mild steel. International Journal of Impact Engineering. 1994. Vol. 15. No. 1. P. 25-39. DOI: https://doi.org/10.1016/S0734-743X(05)80005-3 
4. Pursche F., Meyer L. W. Correlation between dynamic material behavior and adiabatic shear phenomenon for quenched and tempered steels. Engineering Transactions. 2011. Vol. 59. No. 2. P. 67-84.

5. Xu Z., Ding X., Zhang W., Huang F. A novel method in dynamic shear testing of bulk materials using the traditional SHPB technique. Int. J. Impact Eng. 2017. Vol. 101. P. 90-104. DOI: https://doi.org/10.1016/j.ijimpeng.2016.11.012

6. Clos R., Schreppel U., Veit P. Temperature, microstructure and mechanical response during shear-band formation in different metallic materials. Journal de Physique. 2003. Vol. 110. No. 4. P. 111-116. DOI: https://doi.org/10.1051/jp4:20020679

7. Wei Z., Li Y., Li J., Hu S. Formation mechanism of adiabatic shear band in Tungsten heavy alloys. Acta metallurgica sinica. 2000. Vol. 36. No. 12. P. 1263-1268. [In Chinese].

8. Kalthoff J. F. Modes of dynamic shear failure in solids. International Journal of Fracture. 2000. Vol. 101. P. 1-31. DOI: https://doi.org/10.1023/A:1007647800529

9. Dorogoy A., Rittel D., Godinger A. A shear-tension specimen for large strain testing. Experimental Mechanics. 2015. Vol. 56. No. 3. P. 437-449. DOI: https://doi.org/10.1007/s11340-015-0106-1

10. Meyer L. W., Staskewitsch E., Burblies A. Adiabatic shear failure under biaxial dynamic compression/shear loading. Mechanics of Materials. 1994. Vol. 17. No. 2-3. P. $203-214$. DOI: https://doi.org/10.1016/0167-6636(94)90060-4

11. Yu J., Li J, Wei Z. Researches on adiabatic shear failure of tungsten heavy alloy and Ti6Al4V alloy. J. Ningbo Univ. 2003. Vol. 16. No. 4. P. 417-428. DOI: https://doi.org/10.1046/j.1525-139X.2003.16092.x

12. Dowling A. R., Harding J., Campbell J. D. The dynamic punching of metals. Journal of Institute of Metals. 1970. Vol. 98. P. 215-224.

13. Meyer L. W., Andrade U. R., Chokshi A. H. The effect of grain size on the high-strain, high-strain-rate behavior of copper. Metallurgical and Materials Transactions A. 1995. Vol. 26. P. 2881-2893. DOI: https://doi.org/10.1007/BF02669646

14. Dodd B., Bai Y. Adiabatic shear localization: frontiers and advances. Elsevier, London. 2012. 468 p.

15. Meyer L. W., Halle T. Shear strength and shear failure, overview of testing and behavior of ductile metals. Mech. Time-Depend Mater. 2011. Vol. 15. P. 327-340. DOI: https://doi.org/10.1007/s11043-010-9113-x

16. Rittel D., Lee S., Ravichandran G. A Shear-compression specimen for large strain testing. Exp. Mech. 2002. Vol. 42. P. 58-64. DOI: https://doi.org/10.1007/BF02411052

17. Ferguson W. G., Hauser F. E., Dorn J. E. Dislocation damping in zinc single crystals. Brit. J. Appl. Phys. 1967. Vol. 18. P. 411-417. DOI: https://doi.org/10.1088/0508-3443/18/4/304

18. Степанов Г. В. Упругопластическое деформирование и разрушение материалов при импульсном нагружении. Киев: Наук. думка, 1991. 288 с.

19. Степанов Г. В., Федорчук В. А. Локализованный сдвиг в металлах при ударном нагружении. Проблемы прочности. 2000. № 2. С. 27-42.

20.Xu Z., Ding X., Zhang W., Huang F. A novel method in dynamic shear testing of bulk materials using the traditional SHPB technique. Int. J. Impact Eng. 2017. Vol. 101. P. 90-104. DOI: https://doi.org/10.1016/j.ijimpeng.2016.11.012

21. Peirs J. et al. The use of hat-shaped specimens to study the high strain rate shear behaviour of Ti-6Al-4V. International Journal of Impact Engineering. 2010. Vol. 37. P. 703-714. DOI: https://doi.org/10.1016/j.ijimpeng.2009.08.002

22. $\mathrm{Xu} \mathrm{Z}$. et al. Plastic behavior and failure mechanism of Ti-6Al-4V under quasi-static and dynamic shear loading. International Journal of Impact Engineering. 2019. Vol. 130. P. 281-291. DOI: https://doi.org/10.1016/j.ijimpeng.2019.04.008

23. Johnson G. R, Cook W. H. Fracture characteristics of three metals subjected to various strains, strain rates, temperatures and pressures. Eng. Fracture Mech. 1985. Vol. 21. P. 31-48. DOI: https://doi.org/10.1016/0013-7944(85)90052-9

24. Hancock J. W., Mackenzie A. C. On the mechanisms of ductile failure in high-strength steels subjected to multi-axial stress-states. J. Mech. Phys. Solids. 1976. Vol. 24. P. 147-169. DOI: https://doi.org/10.1016/0022-5096(76)90024-7

25. Iqbal M. A., Senthil K., Sharma P., Gupta N. K. An investigation of the constitutive behavior of Armox $500 \mathrm{~T}$ steel and armor piercing incendiary projectile material. International Journal of Impact Engineering. 2016. Vol. 96. P. 146-164. DOI: https://doi.org/10.1016/j.ijimpeng.2016.05.017 


\title{
УДК 539.4
}

\section{ЧИСЕЛЬНЕ МОДЕЛЮВАННЯ ВИПРОБУВАНЬ НА ДИНАМІЧНИЙ ЗСУВ ЗРАЗКІВ ІЗ ВИСОКОМІЩНИХ СТАЛЕЙ}

\author{
Свген Кондряков; Валерій Харченко
}

\author{
Інститут проблем міцності імені Г. С. Писаренка НАН Украӥни, \\ Київ, Украӥна
}

\begin{abstract}
Резюме. Для розроблення методики проведення випробувань на динамічний зсув зразків із високоміцних сталей проведено серію чисельних розрахунків із використанням методу скінчених елементів. За результатами аналізу літературних джерел та сучасних методів випробувань на ударний зсув для досліджень обрано форму зразка з двома зонами зсуву. Побудовано розрахункові моделі та проаналізовано вплив розміру скінчених елементів на отримані результати. Для оптимізачії схеми навантаження та реалізації умов чистого зсуву при розрахунках варіювались різні параметри, такі, як розміри зразка та довжину зон зсуву L, розміри ударника, швидкість навантаження, граничні умови тощя. Отримані результати показали, щу зі збільшенням довжини L область чистого зсуву зменшується й локалізується в цеентральній частині. При цььому швидкість деформацій збільшується при зменшенні довжини зон зсуву L. Для зменшення зони зсуву та енергї̈ руйнування запропоновано конструкцію зразка з додатковими бічними надрізами. В таких зразках деформачії зсуву зростають, відповідно умови деформування більш наближені до чистого зсуву. Показано, шуо радіус фасок виточок у зоні зсуву майже не впливає на отримані результати. Використовуючи модель Джонсона-Кука $з$ урахуванням впливу швидкості деформації, проведено моделювання руйнування зразків із броньованої сталі Агтох $500 T$ із застосуванням відповідного критерію руйнування. Результати розрахунків показали, що початок руйнування відбувається в момент часу $t$ 500 мкс у зонах концентраторів напружень (фасок). Далі розповсюдження тріщини відбувається вздовж зони зсуву. Таким чином така конструкція зразка та схема навантаження повинна забезпечити реалізаџію умов чистого зсуву.

Ключові слова: динамічний зсув, швидкість деформації, метод скінчених елементів,
\end{abstract} високоміцні сталі. 